\title{
Leaf versus root nitrogen uptake by the surfgrass Phyllospadix torreyi
}

\author{
J. Terrados*, S. L. Williams \\ Department of Biology, San Diego State University, San Diego, California 92182-4614, USA
}

\begin{abstract}
Phyllospadix torreyi S. Watson ('surfgrass') is one of very few seagrass species that grow on rocks. Thus, unlike most other seagrasses, nutrient uptake across leaves rather than across roots might be very important for nutrient acquisition. Ammonium and nitrate+nitrite uptake by surfgrass leaves was measured under flowing water and modelled (Michaelis-Menten) as a function of external

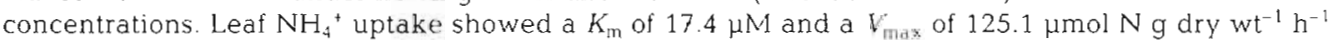

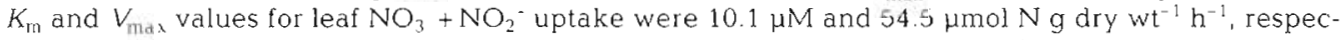
tively. Ammonium available to the roots had little discernible effect on $\mathrm{NH}_{4}{ }^{+}$uptake by leaves. Low $\mathrm{NH}_{4}{ }^{+}$uptake rates by roots $\left(<0.2 \mu \mathrm{mol} \mathrm{Ng}\right.$ dry $\left.\mathrm{wt}^{-1} \mathrm{~h}^{-1}\right)$ suggest that surfgrass acquires most of its nitrogen via its leaves.
\end{abstract}

KEY WORDS: Ammonum - Nitrate Leaf uptake Root uptake Phyllospadix - Seagrasses

\section{INTRODUCTION}

The seagrass species of the genus Phyllospadix Hook. grow on rocky substrata in high-energy environments (Dudley 1894, den Hartog 1970). This habitat is distinctly different from that of most other seagrasses that grow on unconsolidated substrata (mud, sand), and where the amount of physical energy imposes limits on the development of meadows (Fonseca \& Kenworthy 1987). These physical differences of the habitat have implications for community processes such as nutrient cycling, community stability and succession (McRoy \& Lloyd 1981), and suggest that Phyllospadix beds could be more similar to macroalgae communities than to other seagrass beds. In fact, Phyllospadix is able to compete successfully with macroalgae for space and form communities with high persistence (Turner 1983a, b, 1985. Turner \& Lucas 1985).

Seagrasses can take up inorganic nutrients present both in the water column and the sediment via leaf and/or root uptake. Although the sediments have been considered the main nutrient source for seagrasses

\footnotetext{
- Present address: Centro de Estudios Avanzados de Blanes, C.S.I.C., Camí de Santa Bárbara, s/n, E-17300 Blanes (Girona),Spain. E-mail: terrados@ceab.es
}

(McRoy \& Barsdate 1970, McRoy \& Goering 1974, McRoy \& McMillan 1977, Penhale \& Thayer 1980. Short \& McRoy 1984, Thursby \& Harlin 1984), the importance of leaf uptake has been stressed lately (Patriquin 1972, Borum et al. 1989. Hemminga et al. 1991, 1994, Pedersen \& Borum 1992, 1993). Some of the features of Phyllospadix habitat (surf exposure, rocky substratum) suggest that Phyllospadix would take up the nutrients mainly from the water column via leaf uptake. Seagrasses apparently have complex source-sink interactions between leaves and belowground organs and the nutrient uptake rate and tissue concentration of one can influence those of the other (Thursby \& Harlin 1982, 1984) The relative contribution of leaves and roots to whole plant acquisition of nutrients must depend on kinetic attributes of the different tissues, nutrient concentrations available to each type of tissue, their biomasses, and nutrient flux rates.

Phyllospadix species show some anatomical features that have been interpreted as adaptations to surf exposure (Cooper \& McRoy 1988, Barnabas 1994). Extensive root-hair development (Cooper \& McRoy 1988), a well-developed mechanical layer (i.e. thick-walled compactly arranged cells without any air spaces) in the outer cortex of the root, a thickened outer wall of root 
epidermal cells, and the production of a mucilaginouslike material by the roots as an adhesive to the substratum (Barnabas 1994) are some of the potentially adaptive features for life on rocks with high surf exposure. The essential function of the roots of Phyllospadix is considered to be attachment, not nutrition (Gibbs 1902, C. McMillan, p 236, in Stewart 1989). However, the extensive development of root hairs suggests that surfgrass could obtain a significant portion of inorganic nutrients through its roots (Cooper \& McRoy 1988). Further, the pectin-rich layer present in the outer wall of root epidermal cells of Phyllospadix scouleri Hook. could be involved in nutrient absorption (Barnabas 1994). Presently there is no experimental evidence to support or reject a role of Phyllospadix roots in nutrient acquisition. The roots of Thalassodendron ciliatum, one of the other few seagrass species that can grow on a rocky substrate, are surmised to have limited nutrient absorption capacity (Barnabas 1991).

This study aims to describe the nitrogen (ammonium, nitrate+nitrite) uptake by the leaves and roots of Phyllospadix torreyi S. Watson, and their interaction, through answering the following questions: Is P. torreyi able to acquire nutrients via the roots? How do ambient nitrogen concentrations compare to uptake kinetic parameters? Does leaf/root ammonium uptake change when the roots/leaves are supplied with ammonium?

\section{MATERIALS AND METHODS}

Study site. Surfgrass Phyllospadix torreyi S. Watson is abundant on the upper subtidal rocky bottoms of the San Diego County, Southern California (USA), coast (Stewart \& Myers 1980, Stewart 1989); all plants used here were collected in the False Point area, La Jolla $\left(32^{\circ} 48^{\prime} \mathrm{N}, 117^{\circ} 16^{\prime} \mathrm{W}\right)$. This stretch of the coast is openly exposed to the ocean swell. Different types of substrata can be found in the area: rocky outcrops, coarse sands, and cobble beaches. Surfgrass is distributed from the mean-lower-low-water (MLLW) level into the upper subtidal, $\approx-5 \mathrm{~m}$ (Ricketts et al. 1985), forming patches always located on rocks or big boulders, sometimes buried under a thin (less than $2 \mathrm{~cm}$ ) layer of coarse sand. The plants used in the experiments came from surfgrass patches present in an area of roughly $100 \times 200 \mathrm{~m}$ along the shore at a depth (MLLW) of $-3 \mathrm{~m}$ (Fig. 1). The study was done between February 1993 and December 1994.

Water samples for analysis of dissolved inorganic nitrogen (DIN) concentrations $\left(\mathrm{NH}_{4}{ }^{+}, \mathrm{NO}_{3}{ }^{-}+\mathrm{NO}_{2}{ }^{-}\right)$ were collected at 3 locations within the study site: (1) at the water's surface near the shallowest surfgrass patches ('shore'); (2) at the water's surface where plants were collected for experiments ('surface'), ap-

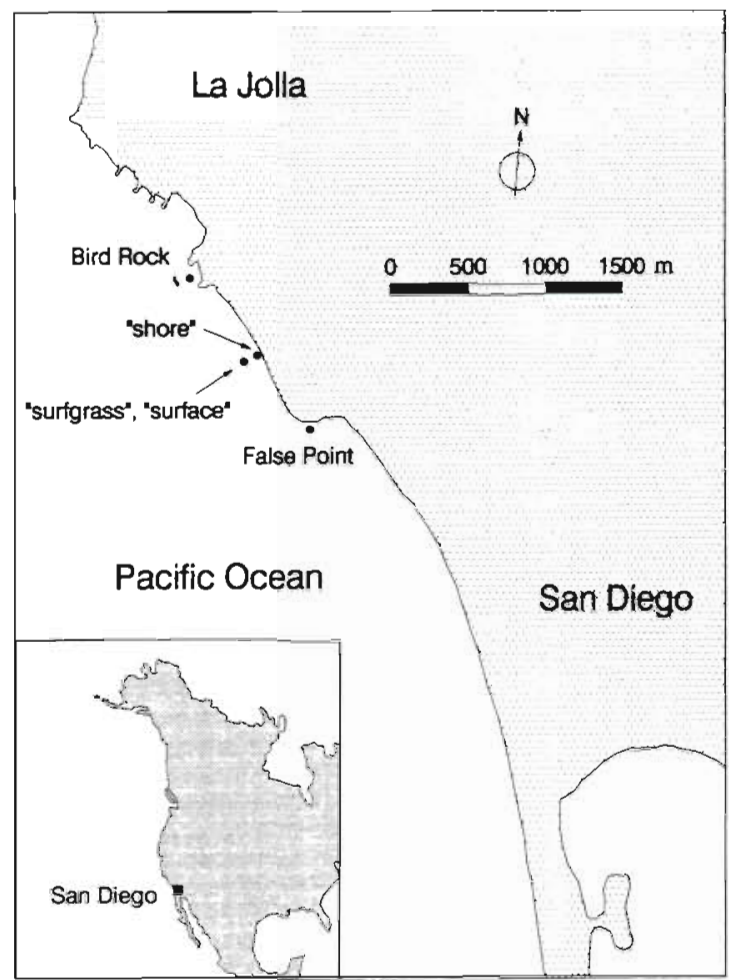

Fig. 1. Station where surfgrass plants for uptake experiments were collected ('surfgrass'), and stations where plant nitrate concentrations ('Bird Rock', 'shore', 'False Point'), temperature, $\mathrm{NH}_{4}{ }^{+}$and $\mathrm{NO}_{3}{ }^{-}+\mathrm{NO}_{2}$ concentrations in the water column ('surfgrass', 'surface', 'shore') and the interstutial water of the sediments ('surfgrass') were measured at False Point, La Jolla (CA, USA)

proximately $200 \mathrm{~m}$ offshore from the first location; and (3) inside the surfgrass canopy ('surfgrass') in the same vicinity as the 'surface' location (Fig. 1). The 'shore' location was the only one sampled for $\mathrm{NO}_{3}{ }^{-}+\mathrm{NO}_{2}$ analysis ( $n=23$ ) between July 1993 and May 1994 (see Fig 2); all 3 locations were sampled for both $\mathrm{NH}_{4}{ }^{+}(\mathrm{n}=$ 21 or 17$)$ and $\mathrm{NO}_{3}{ }^{-}+\mathrm{NO}_{2}(\mathrm{n}=18)$ analysis from June 1994 to December 1994. Five replicate samples were taken in individual acid-washed polycarbonate bottles at each sampling date at each location. The samples $(50 \mathrm{ml})$ were immediately filtered through $2.5 \mathrm{~cm}$ Whatman GF/C filters and $\mathrm{NH}_{4}{ }^{+}$reagents were added to a $10 \mathrm{ml}$ subsample, which was kept cool and dark while transported to the laboratory. Nitrate+nutrite samples were frozen until analysis (less than 1 mo after collection). Ammonium samples were kept in the refrigerator and measured withın $24 \mathrm{~h}$. Water temperature was measured each sampling date at each location (see Fig. 2).

Interstitial water was collected from the water immediately above unvegetated sediments, from sediments without surfgrass, and in sediments with surfgrass by insertion of a 2 -end hypodermic needle wrapped in a 
$30 \mu \mathrm{m}$ mesh into the sediment; when the serum stopper on an evacuated $4 \mathrm{ml}$ glass tube (Vacutainer) was punched through one of the needles, the interstitial water was drawn from the sediment. Samples for $\mathrm{NH}_{4}{ }^{+}$ analysis (sediment with surfgrass, $n=9$; sediment without surfgrass, $\mathrm{n}=7$; above sediment, $\mathrm{n}=3 ; 2$ to 5 replicates per sample) were obtained in July and September 1994; samples for $\mathrm{NO}_{3}{ }^{-}+\mathrm{NO}_{2}$ analysis were collected on 2 different days in January and February 1994.

Nitrate+nitrite was determined with a flow-injection autoanalyzer (Lachat Instruments, Milwaukee, WI, USA) using a Cd-Cu reduction method (Parsons et al 1984). Ammonium was determined using a phenolhypochlorite method (Grasshoff et al. 1983). The redox potential (Eh) of the interstitial water of sediments with and without surfgrass ( $\mathrm{n}=8$ and 3 , respectively; 2 to 5 replicates per sample) and of the water immediately above unvegetated sediment $(n=1)$ was also measured on 4 different days during August and September 1994 using a platinum electrode [calibrated with ZoBell's (1946) solution] and an Ag/AgCl reference electrode with saturated $\mathrm{KCl}$ electrolyte (American Public Health Association 1992). The Eh value of the water samples, corrected for the potential of the reference electrode, is used here to qualitatively describe the degree of anaerobiosis of Phyllospadix torreyi sediments (Whitfield 1969, 1974).

Surfgrass collections for uptake experiments. Both the plants and the water to be used in an experiment were collected $24 \mathrm{~h}$ beforehand. One surfgrass clump (>50 shoots) from 15 to 20 distinct surfgrass patches at the 'surfgrass' location was haphazardly collected by hand and transported to the laboratory in seawater. One whole shoot was selected from each clump to minimize using clonal material. The leaves were cut uniformly to the basal $45 \mathrm{~cm}$. The bundle of 2 to 4 leaves in the shoot was either pinched off the rhizome for leaf uptake experiments or left attached to the rhizome with up to 2 rhizome nodes and with roots on either side of the shoot for leaf versus root uptake experiments. After leaves were cleaned of macroepiphytes, plant fragments were kept in a greenhouse inside a plastic bucket filled with Whatman GF/C filtered seawater which was mixed and aerated by a small aquarium air pump and kept at field temperatures. To insure that plants recovered from collection before being used in the uptake experiments, the respiration rate of whole (leaves with attached rhizome and roots) shoots $(n=6)$ was measured 6,21 and $27 \mathrm{~h}$ after collection. The respiration rates became constant after $21 \mathrm{~h}$ ( $t$-test for paired comparisons between 21 and $27 \mathrm{~h}: t=0.0934, \mathrm{df}=5, \mathrm{p}=$ $0.93)$; thus all nutrient uptake experiments began after $21 \mathrm{~h}$. Ammonium leaching from the cut surfaces of the rhizome and roots was measured in the experimental chambers (see 'Uptake experiments'; $n=7$ experimen- tal chambers, plus 7 control chambers with no plant inside). The mean $( \pm \mathrm{SE})$ leaching rate was $0.13 \pm 0.02$ $\mu \mathrm{mol} \mathrm{Ng}$ dry $\mathrm{wt}^{-1} \mathrm{~h}^{-1}$. For $\mathrm{NO}_{3}+\mathrm{NO}_{2}{ }^{-}$uptake experiments the plants were kept in seawater at $10 \mu \mathrm{M} \mathrm{NO}_{3}$ to induce the nitrate reductase activity (Guerrero et al. 1981, Thursby \& Harlin 1984, Roth \& Pregnall 1988).

The seawater used in the experiments was collected at the shore and filtered once through Whatman GF/C filters and then through Millipore GS filters (pore size, $0.22 \mu \mathrm{m})$. One batch of each of the initial $\mathrm{NO}_{3}{ }^{-}+\mathrm{NO}_{2}{ }^{-}$ or $\mathrm{NH}_{4}^{+}$concentrations needed according to the planned experiment was prepared by adding small volumes (ml) of concentrated $\mathrm{KNO}_{3}$ or $\left(\mathrm{NH}_{4}\right)_{2} \mathrm{SO}_{4}$ solutions to large volumes (l) of water kept in plastic containers. Based on the Eh values obtained (see 'Results'), the oxygen content of the water used in the root compartment was not reduced.

Uptake experiments. Nitrogen uptake experiments were performed in 2-compartment chambers made from a clear acrylic pipe of $25 \mathrm{~mm}$ (internal diameter, i.d.); the leaf compartment was $70 \mathrm{~cm}$ in length, the root compartment was $7.5 \mathrm{~cm}$. A silicone stopper with a small hole drilled at the centre and a slit to facilitate plant placement held the 2 compartments together. The leaves without attached rhizome and roots were fixed to a $20 \mathrm{~cm}$ plastic-coated wire inserted in the hole of the silicone stopper; the leaves with attached rhizome and roots were inserted through the hole in the stopper until the shoot insertion point on the rhizome. The seal between compartments was formed by placing a small amount of 'UHU HOLD-IT Removable Plastic Adhesive' (Eberhard Faber, Inc., Lewisburg, TN, USA) around the leaves inside the stopper hole to fill in gaps and covering the root end of the hole with nontoxic anhydrous lanolin. A water pump (Maxi-jet MJ250, Aquarium Systems, Mentor, OH, USA) placed at one end of the leaf compartment pumped water across the leaves and recirculated it within the chamber via a $1 \mathrm{~cm}$ i.d. PVC tubing This design forced a unidirectional flow of the water inside the leaf compartment from the base of the leaves to the apex at an average velocity of $14 \mathrm{~cm} \mathrm{~s}^{-1}$. A small hole drilled in the chamber wall next to the pump and equipped with a red rubber septum stopper was used for sampling using $5 \mathrm{ml}$ syringes. The root compartment was opaque, unstirred, and had a sampling port.

The experiments were performed during midday under direct sunlight. The chambers were placed horizontally inside a shallow water bath. Water temperature was controlled $\left( \pm 2^{\circ} \mathrm{C}\right.$ ) by 2 cooling units (Aquanetics Systems, San Diego, CA) that recirculated the bath water and by a layer of shadecloth placed over the chambers. Even under the shade, light inside the chambers was always between 140 and $300 \mu \mathrm{mol} \mathrm{m} \mathrm{m}^{-2}$ $\mathrm{s}^{-1}$. The surfgrass habitat at the study site was fre- 
quently quite turbid due to resuspension of detritus and sediments in the surf zone, and light was $69 \mu \mathrm{mol}$ photons $\mathrm{m}^{-2} \mathrm{~s}^{-1}$ over the leaf canopy and $29 \mu \mathrm{mol}$ photons $\mathrm{m}^{2} \mathrm{~s}^{-1}$ within the canopy on the one ocassion light was measured in situ ( $4 \pi$ quantum sensor, Biospherical, Inc., San Diego, CA). The total $\mathrm{CO}_{2}$ content of the water inside the leaf chambers decreased by 0.2 to $0.4 \mathrm{mmol} \mathrm{CO}_{2} \mathrm{I}^{-1}$ during a leaf $\mathrm{NO}_{3}{ }^{-}+\mathrm{NO}_{2}^{-}$uptake experiment, and final $\mathrm{pH}$ values were always $<8.6$; thus, carbon should not have been limiting.

Ammonium and nitrate+nitrite uptake rates were estimated following the 'multiple flask' method (De Boer 1981) from the decline in concentration in the water inside the chambers during periods of 2 to $3 \mathrm{~h}$. Water samples ( $5 \mathrm{ml} ; \mathrm{n}=3$ ) were collected from the chambers at constant time intervals ( 45 to $60 \mathrm{~min}$ ) and kept cool $\left(4^{\circ} \mathrm{C}\right)$ and dark until analysis (less than $24 \mathrm{~h}$ ). Ammonium reagents were added either immediately or within $2 \mathrm{~h}$ after finishing the experiment. After the experiment, the leaf surface area of each plant fragment was measured using a Li-3100 Area Meter (LiCor, Inc., Lincoln, NE, USA) and then the plant fragment was dried at $65^{\circ} \mathrm{C}$ for $24 \mathrm{~h}$ and weighed.

A linear regression between the nutrient concentration inside the chamber and time was obtained for each chamber. If there were non-linearities in the time course, only the initial linear portion was used. The mean of the slopes obtained in the 2 control chambers (without a plant inside) at each concentration was subtracted from the slope obtained in each of the 2 chambers with a plant inside at the same concentration to calculate the net apparent uptake rates, corrected for volume changes along the experiment. The uptake rates were standardized both by biomass ( $g$ dry wt) and shoot leaf surface $\left(\mathrm{cm}^{2}, 2\right.$ sides).

The uptake of $\mathrm{NH}_{4}{ }^{+}$and $\mathrm{NO}_{3}{ }^{-}+\mathrm{NO}_{2}{ }^{-}$was described using a Michaelis-Menten type model $V=\left(V_{\text {max }}(S]\right) /$ $\left(K_{\mathrm{m}}+[S]\right)$, where $[S]$ is the initial concentration of the nutrient inside the chamber $(\mu \mathrm{M}), V$ is the apparent net uptake rate (either $\mu \mathrm{mol} g$ dry $\mathrm{wt}^{-1} \mathrm{~h}^{-1}$ or $\mu \mathrm{mol} \mathrm{cm}^{-2}$ $\left.\mathrm{h}^{-1}\right), V_{\max }$ is maximum uptake rate, and $K_{\mathrm{m}}$ is the [S] value at which $V$ equals $V_{\max } / 2 . K_{\mathrm{m}}$ and $V_{\max }$ were estimated using the Woolf linear transformation, $[S] / \mathrm{V}=$ $\left(1 / V_{\max }\right)[S]+\left(K_{m} / V_{\max }\right)$, of the Michaelis-Menten equation (Dowd \& Riggs 1965, Segel 1968).

Ammonium uptake of leaves without attached rhizome and roots was measured at initial $\mathrm{NH}_{4}{ }^{+}$concentrations of $1,2,4,8,16,24$ and $32 \mu \mathrm{M}$. Two plants (2 chambers with a shoot inside) and 2 controls ( 2 chambers without plants) were used at each concentration. Experiments were performed on 27 July and 3, 10 and 17 August 1994. Leaves were separated from the rhizome for logistical ease, which could potentially have affected nutrient uptake rates. We therefore compared leaf $\mathrm{NH}_{4}{ }^{+}$uptake rates at $16 \mu \mathrm{M}$ for leaves with and without the rhizome ( $\mathrm{n}=9$ replicates). There was no significant difference between rates ( $p>0.05$, MannWhitney $U$-test).

Nitrate+nitrite uptake of leaves without attached rhizome and roots was measured at the initial nitrate concentrations of $2,4,8,24$ and $32 \mu \mathrm{M}$. Two plants ( 2 chambers, each with a shoot inside) and 2 controls ( 2 chambers without plants) were used at each concentration. Experiments were performed on 13 and 4, 11 , 18 and 25 May 1994.

Nitrogen uptake rates are controlled by the different internal N pools (D'Elia \& De Boer 1978, Harrison \& Druehl 1982, Thomas \& Harrison 1985. Hwang et al. 1987, Pedersen 1994, McGlathery et al. 1996). We measured the internal $\mathrm{NO}_{3}^{-}$pool in surfgrass leaves ( $n=6$ each) from 2 points (about $100 \mathrm{~m}$ apart) at each of 3 places within the study area (Fig 1) following methods of Williams \& Herbert (1989). Dissolved $\mathrm{NO}_{3}{ }^{-}$ concentrations ranged from $0.57 \pm 0.23$ and $1.22 \pm$ $0.03 \mu \mathrm{mol} N \mathrm{~g}$ dry $\mathrm{wt}^{-1}$ and there were not significant differences between places (Kruskal-Wallis ANOVA, $p=0.17$. We assumed, therefore, that our results are not affected by differences in the internal $\mathrm{NO}_{3}{ }^{-}$pools between shoots. However, this is only a partial analysis of the problem (Pedersen 1994, McGlathery et al. 1996), and we cannot exclude the possibility that our results might be affected by differences in other internal $\mathrm{N}$ pools $\left(\mathrm{NH}_{4}^{+}\right.$, amino compounds) between shoots.

To assess the effect of $\mathrm{NH}_{4}{ }^{+}$availability to the roots on leaf $\mathrm{NH}_{4}^{+}$uptake rates, 3 experiments were performed (during November and December 1994) where the leaf and root uptake rates of $\mathrm{NH}_{4}{ }^{+}$were measured in shoots with or without $\mathrm{NH}_{4}{ }^{+}$available to the roots. Each experiment had 5 replicates for each of the following conditions: (1) shoots with attached rhizome and roots that had $16 \mu \mathrm{M}$ in the leaf compartment and $20 \mu \mathrm{M}$ in the root compartment, (2) shoots with attached rhizome and roots that had $16 \mu \mathrm{M}$ in the leaf compartment and $<1 \mu \mathrm{M}$ in the root compartment, (3) shoots with attached rhizome and roots that had $<1 \mu \mathrm{M}$ in the leaf compartment and $20 \mu \mathrm{M}$ in the root compartment, and (4) control chambers (no plant inside) that had $16 \mu \mathrm{M}$ in the leaf compartment and $20 \mu \mathrm{M}$ in the root compartment. In nature, surfgrass is exposed to higher $\mathrm{NH}_{4}^{+}$concentrations in the sediment than in the water column. Condition 3 best represents the conditions in the surfgrass habitat (see 'Results'), but the root compartment concentration was roughly $2 \times$ ambient. The concentrations used, however, were chosen a priori based on the $K_{\mathrm{m}}$ obtained for leaves (see 'Results') in earlier experiments.

Biomass allocation to leaves, rhizome and roots. $A$ quantification of the surfgrass biomass allocation to leaves and roots is necessary to scale leaf and root uptake rates to $\mathrm{N}$ acquisition by the whole plant. Eleven 
surfgrass samples $\left(165 \mathrm{~cm}^{2}\right)$ were collected haphazardly in October 1994 and cleaned of sediment and macroepiphytes, separated into leaves versus rhizomes and roots, dried at $65^{\circ} \mathrm{C}$ during $48 \mathrm{~h}$, and weighed. The dried samples were ground to a fine powder and 3 subsamples of approximately $0.5 \mathrm{~g}$ were combusted at $500^{\circ} \mathrm{C}$ during $4 \mathrm{~h}$ to determine their ash content.

\section{RESULTS}

\section{Surfgrass habitat characterization}

Water temperature at the study site varied from $14.5-16^{\circ} \mathrm{C}$ in January-March 1994 to $22-23.5^{\circ} \mathrm{C}$ in JulySeptember 1994 (Fig. 2a). The average concentration of $\mathrm{NO}_{3}{ }^{-}+\mathrm{NO}_{2}{ }^{-}$in the water column was $0.40 \pm 0.10$ (mean \pm SE) $\mu \mathrm{M}$, and $0.42 \pm 0.11 \mu \mathrm{M}$ for $\mathrm{NH}_{4}{ }^{+}$(see Table 4). Nitrate+nitrite concentrations reached maximum values $(\approx 1$ or $2 \mu \mathrm{M})$ in July and August for 1993 and in August to October for 1994 (Fig. 2b). Ammonium concentration in the water column showed no seasonal pattern from May to December 1994 (Fig. 2C). The availability of DIN in the sediment was 1 order of magnitude higher than in the water column. Eh values were always positive, ranging from +258 to $+326 \mathrm{mV}$ (Table 1 ).

\section{Uptake experiments}

Typical time-courses of $\mathrm{NH}_{4}{ }^{+}$and $\mathrm{NO}_{3}{ }^{-}+\mathrm{NO}_{2}{ }^{-}$concentrations inside the chambers are presented for the experiments performed on 17 August 1994 (Fig. 3a) and 13 April 1994 (Fig 3b), respectively. Leaf $\mathrm{NH}_{4}{ }^{+}$ uptake fitted a Michaelis-Menten type model both for

Table 1. Ambient nutrient levels at the study site (False Point, La Jolla, CA, USA). n: number of samples

\begin{tabular}{|llrl|}
\hline & Sampling station & Mean $\pm \mathrm{SE}(\mu \mathrm{M})$ & $\mathrm{n}$ \\
\hline Water column & & & \\
Nitrate+nitrite & Shore & $0.22 \pm 0.05$ & 41 \\
& Surface & $0.42 \pm 0.12$ & 18 \\
& Surfgrass & $0.40 \pm 0.10$ & 18 \\
Ammonium & Shore & $0.85 \pm 0.33$ & 21 \\
& Surface & $0.38 \pm 0.10$ & 17 \\
& Surfgrass & $0.42 \pm 0.11$ & 17 \\
Interstitial water & & \\
Nitrate+nitrite & Phyllospadix patch & $4.78 \pm 0.91$ & 5 \\
Ammonium & Phyllospadix patch & $9.58 \pm 1.43$ & 9 \\
& Bare sand & $12.29 \pm 2.54$ & 7 \\
& Over sediment surface & $3.05 \pm 0.59$ & 3 \\
Eh & Phyllospadix patch & $+285 \pm 19 \mathrm{mV}$ & 8 \\
& Bare sand & $+326 \pm 20 \mathrm{mV}$ & 3 \\
& Over sediment surface & $+258 \mathrm{mV}$ & 1 \\
\hline
\end{tabular}
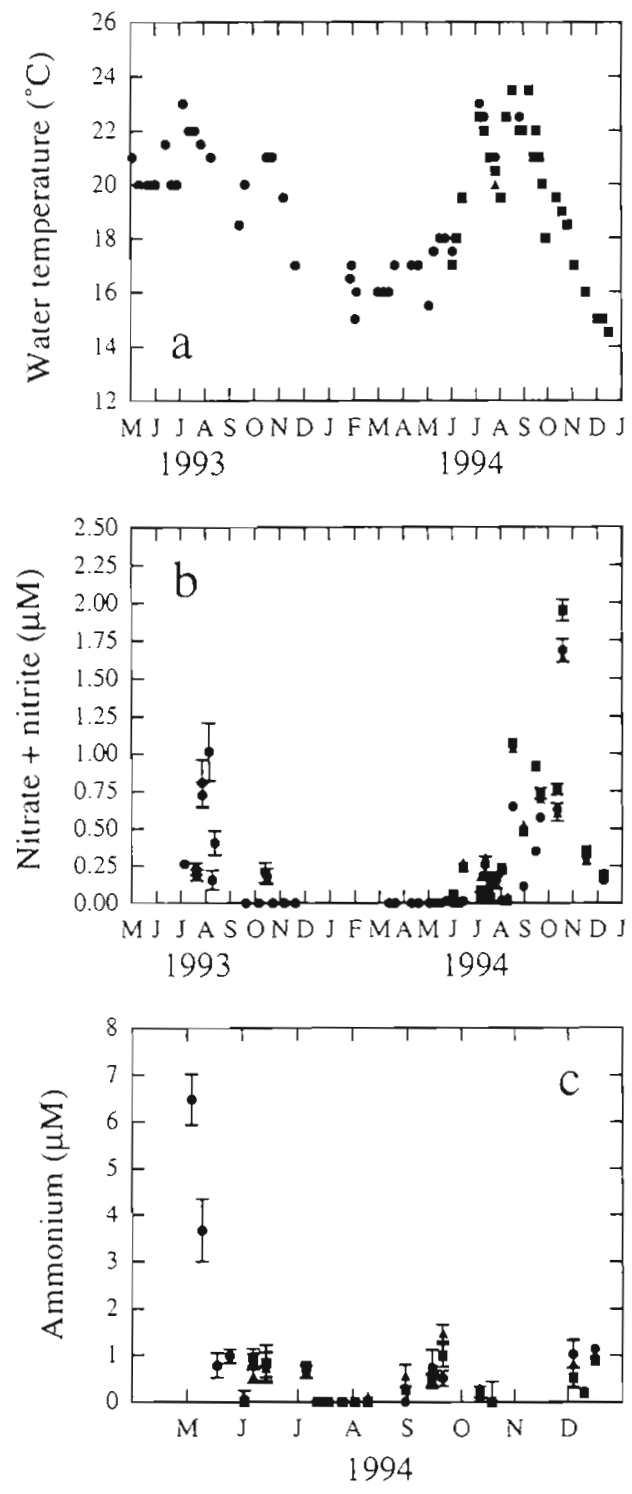

Fig. 2. (a) Temperature; (b) $\mathrm{NO}_{3}{ }^{-}+\mathrm{NO}_{2}{ }^{-}$; and (c) $\mathrm{NH}_{4}{ }^{*}$ concentrations of the water at False Point during the period of study. Locations: (1) 'shore', (-) 'surface', and (4) 'surfgrass' Bars indicate $\pm 1 \mathrm{SE}$ (n values in Table 1)

each individual experiment and for the pooled results of the 4 experiments (Table 2, Fig. 4). The coefficient of determination of the Woolf plot of the data standardized by dry mass was $R^{2}=0.65$, resulting in a significant regression coefficient $(p<0.0001)$ and constant $(p<0.0001)$. The results were similar when standardized by surface area. The mean $( \pm \mathrm{SE}) K_{\mathrm{m}}$ for the 4 experiments was $17.4 \pm 5.60 \mu \mathrm{M}$, and the mean $V_{\text {max }}$ was $125.1 \pm 26.43 \mu \mathrm{mol} \mathrm{N} \mathrm{g} \mathrm{dry} \mathrm{wt}^{-1} \mathrm{~h}^{-1}$

Leaf $\mathrm{NO}_{3}{ }^{-}+\mathrm{NO}_{2}^{-}$uptake also fitted a MichaelisMenten type model for each individual experiment and for the pooled results of the 5 experiments (Table 2, Fig. 5). The coefficient of determination of the 

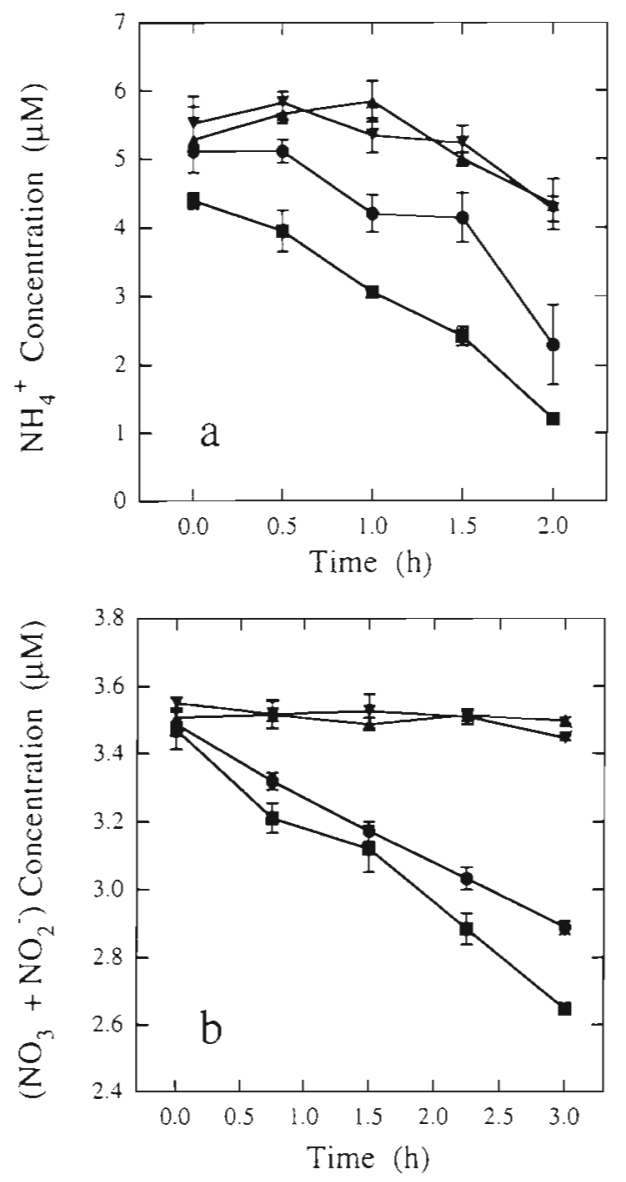

Fig. 3. Typical time-courses of (a) $\mathrm{NH}_{4}{ }^{+}(17 \mathrm{Aug}$ 1994) and (b) $\mathrm{NO}_{3}^{-}+\mathrm{NO}_{2}^{-}$(13 Apr 1994) concentration inside the chambers during the experiments. $(\boldsymbol{\Lambda}, \boldsymbol{\nabla})$ Control chambers; plant chambers. Bars represent \pm 1 SE $(n=3)$

Woolf plot of the data standardized by dry mass was $\mathrm{R}^{2}=0.59$, resulting in a significant regression coefficient $(p<0.0001)$ and constant $(p<0.01)$. The results were similar when standardized by surface. The mean ( $\pm \mathrm{SE}$ ) $K_{\mathrm{m}}$ for the 5 experiments was $10.1 \pm 2.17 \mu \mathrm{M}$, and the mean $V_{\max }$ was $54.5 \pm 9.16 \mu$ mol $\mathrm{Ng}$ dry $\mathrm{wt}^{-1}$ $\mathrm{h}^{-1} . K_{\mathrm{m}}$ values increased from the first experiment (13 April 1994) to the last (25 May 1994); $V_{\text {max }}$ values showed no clear trend (Table 2).

Ammonium depletion in the root chambers was small (Fig. 6) and on the order of the estimated lower limit of sensitivity of the experimental setup used $\left(0.5 \mu \mathrm{M} \mathrm{h} h^{-1}\right.$, or $0.1 \mu \mathrm{mol} g$ dry $\left.w^{-1} h^{-1}\right)$. The results from 2 other experiments supported the same pattern of minimal or undetectable (within limits of experimental protocol) root uptake when roots were supplied with $20 \mathrm{\mu M} \mathrm{NH}_{4}{ }^{+}$, and suggest that roots and rhizomes contributed little to $\mathrm{N}$ acquisition by surfgrass.

Leaf uptake of $\mathrm{NH}_{4}{ }^{+}$was not affected by the availability of $\mathrm{NH}_{4}{ }^{+}$in the root chambers (Table 3). When $\mathrm{NH}_{4}{ }^{+}$was supplied to the roots, the uptake rate by the
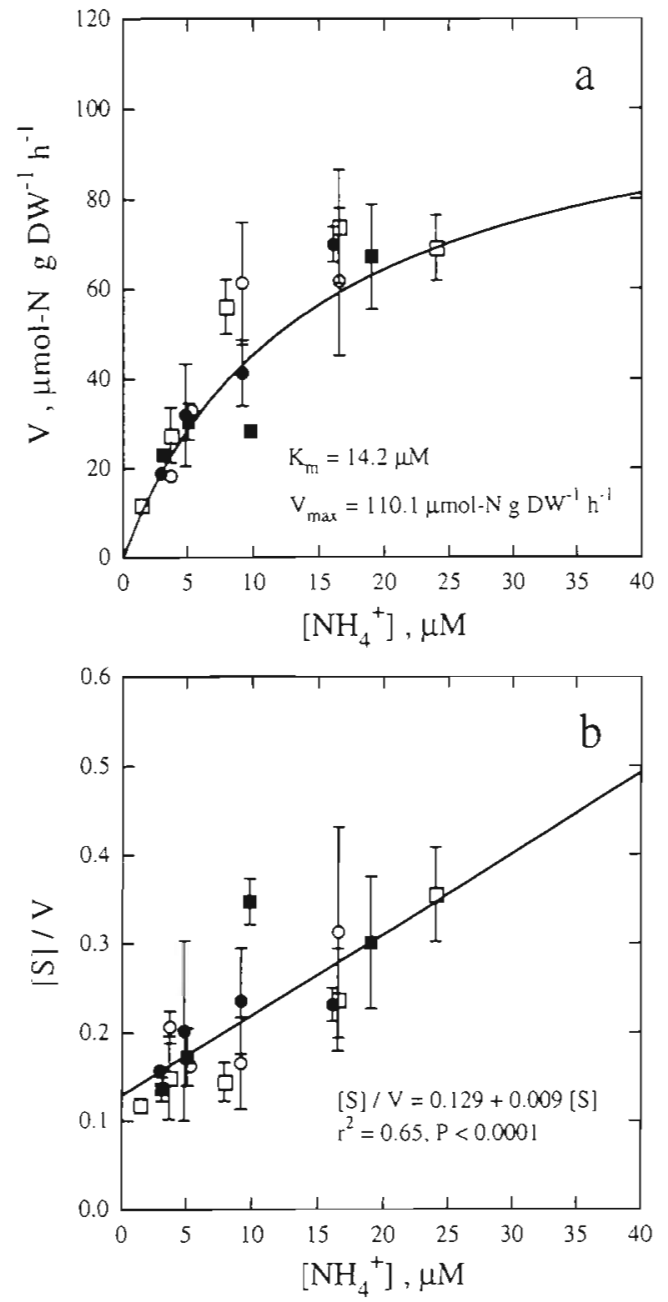

Fig. 4. Leaf $\mathrm{NH}_{4}{ }^{+}$uptake rates of Phyllospadix torreyl. (a) $V$ vs [S] plot of all the experiments performed. The line represents the Michaelis-Menten equation obtained for the pooled results (see Table 2). (b) Woolf plots. All points with the same symbol belong to the same experiment: (O) 27 Jul 1994, (•) 3 Aug 1994, () 10 Aug 1994, and (ロ) 17 Aug 1994. Bars represent $\pm 1 \operatorname{SE}(n=2)$

leaves changed maximally by $58 \%$ and differed little, was lower, or was higher than when the roots were not supplied with $\mathrm{NH}_{4}{ }^{+}$. Only in 1 of the 3 experiments was the difference significant. Hence no strong effect of $\mathrm{NH}_{4}{ }^{+}$availability to the roots was evident, as the pooled results of the 3 experiments show (Table 3 ). The lack of a trend in these results was not surprising given that roots had limited capacity for taking up $\mathrm{NH}_{4}{ }^{+}$.

The density of shoots in October (probably varies seasonally) within surfgrass patches was $6232 \pm 416$ ( $n=11$ ) shoots $m^{-2}$. The total biomass of surfgrass was $2576 \pm 255 \mathrm{~g}$ (ash-free dry wt) $\mathrm{m}^{-2}$ within the patches sampled. Surfgrass allocates the majority of its biomass to leaves; the percentages of biomass allocated to leaves, rhizomes and roots were $76.6 \pm 1.96 \%, 19.9 \pm$ $1.82 \%$, and $3.5 \pm 0.34 \%$, respectively. 
Table 2. Linear regressions of [S]/V vs [S] (Woolf transformation) and derived parameter estimates of the Michaelis-Menten model for $\mathrm{NH}_{4}{ }^{+}$and $\mathrm{NO}_{3}{ }^{-}+\mathrm{NO}_{2}$ uptake by leaves of Phyllospadix torreyi $\mathrm{S}$. Watson. Results of each experiment performed and the pooled results of the experiments are presented. $n$ : number of points used in the regression model

\begin{tabular}{|c|c|c|c|c|c|c|c|}
\hline \multicolumn{2}{|c|}{$\begin{array}{l}\text { Date } \\
\quad \text { Regression parameters }\end{array}$} & \multirow{6}{*}{$\begin{array}{l}K_{\mathrm{m}} \\
{[\mu \mathrm{M})} \\
12.64\end{array}$} & \multirow{2}{*}{$\underset{V_{\max }}{\left(\mu m o l g \mathrm{dry}^{-1} \mathrm{~h}^{-1}\right)}$} & \multicolumn{2}{|c|}{$\begin{array}{l}\text { Date } \\
\text { Regression parameters }\end{array}$} & \multirow{4}{*}{$\begin{array}{c}K_{\mathrm{m}} \\
(\mu \mathrm{M}) \\
4.39\end{array}$} & \multirow{4}{*}{$\begin{array}{c}V_{\max } \\
\left(\mu \mathrm{mol} \mathrm{g} \mathrm{DW}^{-1} \mathrm{~h}^{-1}\right) \\
24.97\end{array}$} \\
\hline 27 Jul 1994 & & & & 13 Apr 1994 & & & \\
\hline Constant (SE) & $0.125(0.051)$ & & 100.76 & Constant (SE) & $0.176(0.099)$ & & \\
\hline Coeff. (SE) & $0.010(0.005)$ & & & Coeff (SE) & $0.040(0.004\}$ & & \\
\hline $\mathrm{R}^{2}$ & 0.643 & & & $\mathrm{R}^{2}$ & 0.973 & & \\
\hline $\mathrm{n}$ & 4 & & & n & 5 & & \\
\hline 3 Aug 1994 & & & & 4 May 1994 & & & \\
\hline Constant (SE) & $0.166(0.027)$ & 33.97 & 204.32 & Constant (SE) & $0.123(0.098)$ & 7.42 & 60.56 \\
\hline Coeff. (SE) & $0.005(0.003)$ & & & Coeff. (SE) & $0.016(0.004)$ & & \\
\hline $\mathrm{R}^{2}$ & 0.619 & & & $R^{2}$ & 0.868 & & \\
\hline $\mathrm{n}$ & 4 & & & $\mathrm{n}$ & 5 & & \\
\hline 10 Aug 1994 & & & & 11 May 1994 & & & \\
\hline Constant $(\mathrm{SE})$ & $0.093(0.027)$ & 9.30 & 99.61 & Constant (SE) & $0.214(0.233)$ & 9.22 & 42.97 \\
\hline Coeff. (SE) & $0.010(0.001)$ & & & Coeff. (SE) & $0.023(0.009)$ & & \\
\hline $\mathrm{R}^{2}$ & 0.943 & & & $\mathrm{R}^{2}$ & 0.679 & & \\
\hline $\mathrm{n}$ & 5 & & & $\mathrm{n}$ & 5 & & \\
\hline 17 Aug 1994 & & & & 18 May 1994 & & & \\
\hline Constant (SE) & $0.143(0.084)$ & 13.65 & 95.69 & Constant (SE) & $0.168(0.115)$ & 12.70 & 75.47 \\
\hline Coeff. (SE) & $0.010(0.007)$ & & & Coeff. (SE) & $0.013(0.004)$ & & \\
\hline $\mathrm{R}^{2}$ & 0.539 & & & $\mathrm{R}^{2}$ & 0.749 & & \\
\hline \multirow[t]{6}{*}{$\mathrm{n}$} & 4 & & & $n$ & 5 & & \\
\hline & & & & 25 May 1994 & & & \\
\hline & & & & Constant (SE) & $0.248(0.043)$ & 16.98 & 68.50 \\
\hline & & & & Coeff. (SE) & $0.015(0.002)$ & & \\
\hline & & & & $\mathrm{R}^{2}$ & 0.959 & & \\
\hline & & & & $\mathrm{n}$ & 5 & & \\
\hline \multicolumn{4}{|c|}{ Pooled experiments } & \multicolumn{2}{|c|}{ Pooled experiments } & & \\
\hline Constant (SE) & $0.129(0.002)$ & 14.24 & 110.16 & Constant (SE) & $0.186(0.065)$ & 8.69 & 46.67 \\
\hline Coeff. (SE) & $0.009(0.002)$ & & & Coeff. (SE) & $0.021(0.004)$ & & \\
\hline $\mathrm{R}^{2}$ & 0.652 & & & $\mathrm{R}^{2}$ & 0.591 & & \\
\hline $\mathrm{n}$ & 17 & & & $\mathrm{n}$ & 25 & & \\
\hline
\end{tabular}

\section{DISCUSSION}

Surfgrass lives in a nutrient-poor environment at the study site. Concentrations of DIN in both the water column and interstitial waters of the sediment (Fig. 2, Table 1) are in the low range of the values found in other seagrass meadows (reviewed in Moriarty \& Boon 1989). The low values of DIN observed in the water column were comparable to those previously reported for Southern California coastal waters (Jackson 1977. Zimmerman \& Kremer 1984). The Eh values measured in the interstitial water (Table 1 ) are characteristic of

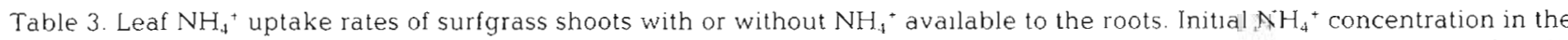
leaf chambers: $16 \mu \mathrm{M}$. Initial $\mathrm{NH}_{4}{ }^{+}$concentration in the root chambers: $<1$ or $20 \mu \mathrm{M}$ acording to treatment. Results of each individual experiment and of the pooled experiments. Means of treatments were compared using the non-parametric Mann-Whitney $U$-test (Sokal \& Rohlf 1981). n: number of replicates

\begin{tabular}{|c|c|c|c|c|c|}
\hline Date & $\begin{array}{l}\text { Ammonium in the root chamber } \\
\qquad(\mu \mathrm{M})\end{array}$ & $\begin{array}{l}\text { Leaf ammonium uptake rate: } \\
\text { mean } \pm S E\left(\mu \mathrm{mol} g \mathrm{DW}^{-1} \mathrm{~h}^{-1}\right)\end{array}$ & $\mathrm{n}$ & $U$ & $\mathrm{p}$ \\
\hline 3 Nov 94 & $\begin{array}{l}20 \\
<1\end{array}$ & $\begin{array}{l}1.72 \pm 0.41 \\
1.47 \pm 0.24\end{array}$ & $\begin{array}{l}5 \\
5\end{array}$ & 11.00 & 0.754 \\
\hline 17 Nov 94 & $\begin{array}{l}20 \\
<1\end{array}$ & $\begin{array}{l}1.91 \pm 0.19 \\
2.66 \pm 0.18\end{array}$ & $\begin{array}{l}5 \\
5\end{array}$ & 3.00 & 0.047 \\
\hline 8 Dec 94 & $\begin{array}{l}20 \\
<1\end{array}$ & $\begin{array}{l}4.67 \pm 0.34 \\
2.95 \pm 0.62\end{array}$ & $\begin{array}{l}5 \\
5\end{array}$ & 5.00 & 0.117 \\
\hline Pooled experiments & $\begin{array}{l}20 \\
<1\end{array}$ & $\begin{array}{l}2.36 \pm 0.27 \\
2.76 \pm 0.40\end{array}$ & $\begin{array}{l}15 \\
15\end{array}$ & 104.0 & 0.724 \\
\hline
\end{tabular}



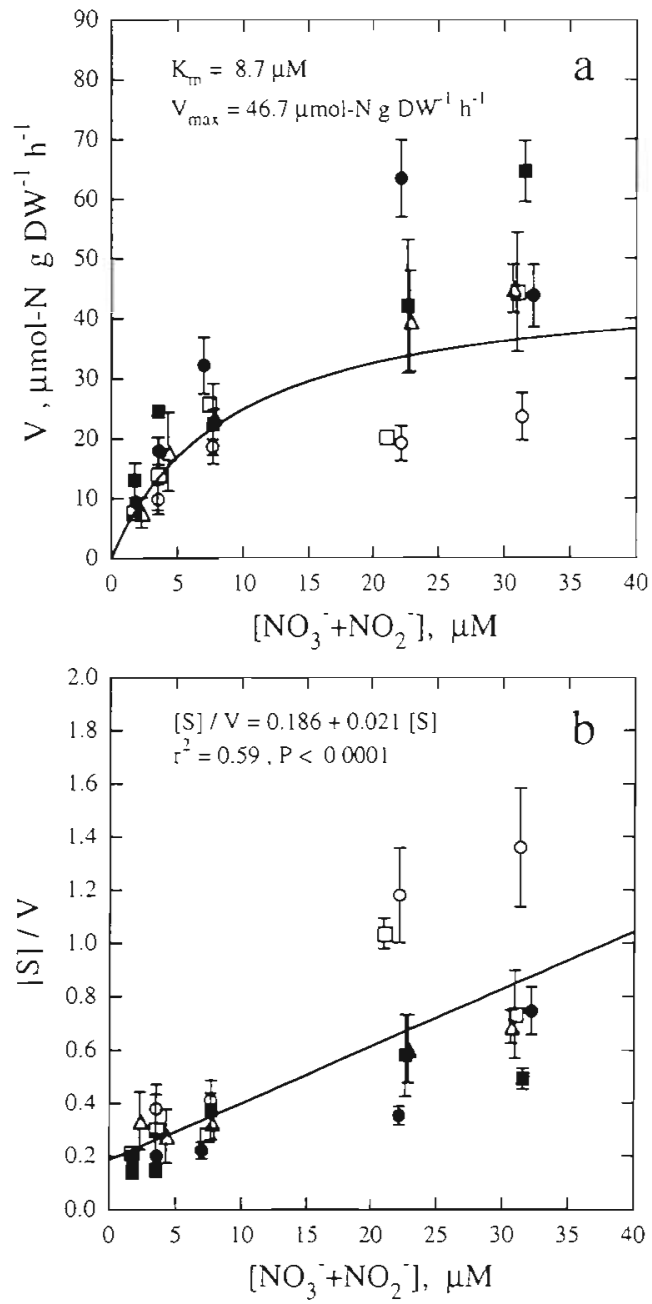

Fig. 5. Leaf $\mathrm{NO}_{3}^{-}+\mathrm{NO}_{2}^{-}$uptake of Phyllospadix torreyi. (a) $\mathrm{V}$ vs [S] plot of all the experiments performed. The line represents the Michaelis-Menten equation obtained for the pooled results (see Table 2). (b) Woolf plots. All points with the same symbol belong to the same experiment: (0) $13 \mathrm{Apr}$ 1994, (-) 4 May 1994,(口) 11 May 1994, (-) 18 May 1994, and

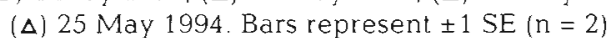

coarse, well-oxygenated sediments or sediments poor in organic matter (ZoBell 1946), and are similar to those found in the upper 2 to $3 \mathrm{~cm}$ of wave-disturbed Thalassia testudinum sediments (Patriquin 1972).

Ammonium and nitrate+nitrite uptake rates by leaves of surfgrass are within the range of those found in other seagrasses (Iizumi \& Hattori 1982, Thursby \& Harlin 1982, 1984, Short \& McRoy 1984, Paling \& McComb 1994, Stapel et al. 1996, Pedersen et al. 1997) and macroalgae (Haines \& Wheeler 1978, O'Brien \& Wheeler 1987, Pedersen 1994, McGlathery et al. 1996). Surfgrass leaf uptake rates of $\mathrm{NH}_{4}{ }^{+}$were higher than those of $\mathrm{NO}_{3}{ }^{-}+\mathrm{NO}_{2}^{-}$(Table 2) as has been also found in Zostera marina (Short \& McRoy 1984) and Amphibolis antarctica (Paling \& McComb 1994).

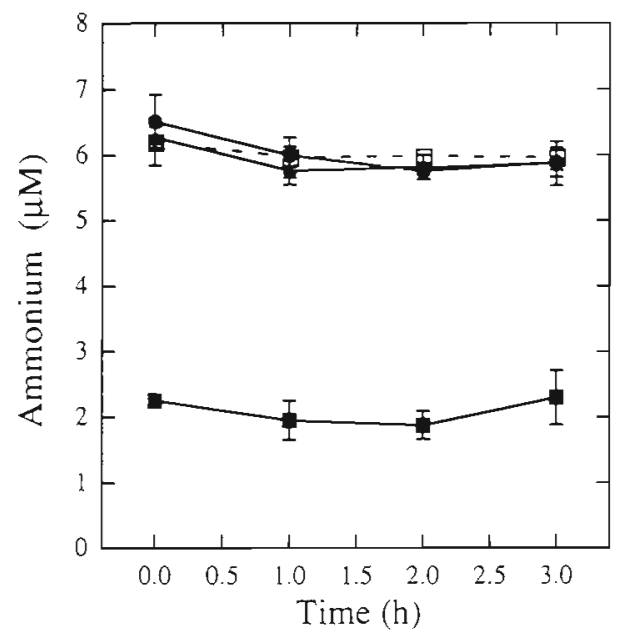

Fig. 6. Mean change in $\mathrm{NH}_{4}{ }^{+}$concentrations inside root chambers with $(\mathbf{\square})$ or without $(\mathbf{\Delta}) \mathrm{NH}_{4}{ }^{+}$available in the leaf compartment, and in control chambers (with no plant inside, $\square$ ) during the 3 Nov 1994 experiment. Bars represent \pm SE of 5 different root chambers

Our results suggest that surfgrass leaves are the primary source of acquired nitrogen and that the roots function primarily in attachment. Although surfgrass roots might take up small amounts of nitrogen, we could not accurately quantify the uptake rate because the changes in concentration in the root chambers were too small $\left(0.1\right.$ to $0.2 \mathrm{~mol} \mathrm{~N} g$ dry $\mathrm{wt}^{-1} \mathrm{~h}^{-1}$. The contention that surfgrass must obtain most of its $\mathrm{N}$ via the leaves is supported by the uptake kinetic results and by the allocation of most of the plant biomass to leaves, in contrast to other seagrass species that live on soft substrata (Stevenson 1988, Hillman et al. 1989). The independence of leaf uptake of $\mathrm{NH}_{4}{ }^{+}$from its availability to the roots (Table 3 ) also supports the conclusion that most of $\mathrm{N}$ acquired by the plant must be channelled through the leaves.

Seagrasses tend to allocate more biomass to rhizomes and roots in sediments where the availability of nutrients is low (Short 1983, 1987, Pérez et al. 1994). Although the surfgrass we studied grows in a nutrientpoor environment, the shallow sediment layer and the presence of rocky substratum beneath might impose overall restrictions to surfgrass rhizome and root biomass allocation. The strength of the root/rhizome attachment in surfgrass is essential for survival in its high-energy habitat (Williams 1995) and indicates that both biomechanical and physiological functions need to be included in considerations of the potentially adaptive significance of biomass allocation strategies in seagrasses, particularly in high-energy environments (Williams 1995).

The rapid water motion of surfgrass habitat probably assures a rapid flux of nutrients to the plants. If the 
concentrations of $\mathrm{NO}_{3}{ }^{-}+\mathrm{NO}_{2}{ }^{-}$and $\mathrm{NH}_{4}{ }^{+}$in the water column at the collection site (Table 1, Fig. 2) are compared with the values of $K_{\mathrm{m}}$ and $V_{\max }$ obtained (Table 2, Figs. 4 \& 5), leaf uptake of DIN by surfgrass would not be saturated under natural conditions Plants could exploit, however, sporadic nutrient pulses advected to the surfgrass beds as has been suggested for Amphibolis antarctica (Pedersen et al. 1997). A complete evaluation of the nutrient supply to surfgrass leaves requires a study of how uptake rates vary with water flow speed.

Seagrasses are clonal plants and the existence of interactions between ramets is undoubtedly important, as has been extensively shown in their land counterparts (Hartnett \& Bazzaz 1983, Pitelka \& Ashmun 1985, Alpert \& Mooney 1986, Slade \& Hutchings 1987 a, b, c, Alpert 1991). Interactions occur both within (leaf-root interactions; Thursby \& Harlin 1982, 1984) and among (interactions between connected shoots; Tomasko \& Dawes 1989, Tomasko et al. 1991) seagrass ramets. The presence of interactions between leaves and roots in nutrient acquisition has been demonstrated for Zostera marina (Thursby \& Harlin 1982) and Ruppia maritima (Thursby \& Harlin 1984), but not for Thalassia hemprichii (Stapel et al. 1996). Our results suggest that these interactions do not occur in Phyllospadix torreyi.

Although nutrient uptake kinetics provides useful insight into the physiological ecology of seagrasses, a dynamic understanding of nutrient supply and demand is critically lacking. For example, the nutrient supply rate to the leaves is a function of both concentration and water flow speeds (Lapointe \& Ryther 1979 , Parker 1981, Harrison \& Druehl 1982, Fujita 1985, Fonseca \& Kenworthy 1987, Atkinson \& Bilger 1992) just as supply to the roots is in part a function of remineralization rates. Also, the nutrient concentration gradient and perhaps flux differential experienced between the aboveground and belowground biomass hypothetically might influence which is the primary site for nutrient acquisition. In turn, this would influence source-sink activity within a clone and the relationship between ramets.

Acknowledgements. This study was funded by the Ministerio de Educación y Ciencia, Programa de Becas de Formación de Personal Investigador en el Extranjero through a fellowship awarded to J.T We thank Dr Joy Zedler for providing access to the flow-injection autoanalyzer and the spectrophotometer. Jim Zimmer provided valuable assistance in the construction of the incubation chambers and the water bath, as did Angela Andrews for the autoanalyzer. Pat Ewanchuk, Jeanne Burch, Amy Sewell, Phillip Larkin and Dr Thorsten Reusch helped in the field and laboratory. We are also thankful for the comments and thorough editing of a previous version of the manuscript by Dr Morten F. Pedersen, as well as those of 2 anonymous reviewers. This is contribution 280 from the Coastal and Marine Institute, San Diego State University.

\section{LITERATURE CITED}

Alpert P (1991) Nitrogen sharing among ramets ıncreases clonal growth in Fragaria chiloensis. Ecology 72:69-80

Alpert P. Mooney HA (1986) Resource sharing among ramets in the clonal herb, Fragaria chiloensis. Oecologia 70 : $227-233$

American Public Health Association (1992) Standard methods for the examination of water and wastewater American Public Health Association, Washington, DC

Atkınson MJ, Bilger RW (1992) Effects of water velocity on phosphate uptake in coral reef-flat communities. Limnol Oceanogr 37:273-279

Barnabas AD (1991) Thalassodendron ciliatum (Forssk.) den Hartog: root structure and histochemistry in relation to apoplastic transport. Aquat Bot 40:129-143

Barnabas AD (1994) Anatomical, histochemical and ultrastructural features of the seagrass Phyllospadix scoulen Hook. Aquat Bot 49:167-182

Borum J, Murray L, Michael Kemp W (1989) Aspects of nitrogen acquisition and conservation in eelgrass plants. Aquat Bot 35:289-300

Cooper LW, McRoy CP (1988) Anatomical adaptations to rocky substrates and surf exposure by the seagrass genus Phyllospadix. Aquat Bot 32:365-381

DeBoer JA (1981) Nutrients. In: Lobban CS, Wynne MJ (eds) The blology of seaweeds. Blackwell Scientific Publications, London, p 356-392

D'Elia CF, DeBoer JA (1978) Nutritional studies of two red algae. 11. Kinetics of ammonium and nitrate uptake. J Phycol 14:266-272

den Hartog C (1970) The seagrasses of the world. NorthHolland Publishing, Amsterdam

Dowd JE, Riggs DS (1965) A comparison of estimates of Michaelis-Menten kinetic constants from various linear transformations. J Biol Chem 240:863-869

Dudley WR (1894) Phyllospadix, its systematic characters and distribution. Zoe 4:381-385

Fonseca MS, Kenworthy WJ (1987) Effects of current on photosynthesis and distribution of seagrasses. Aquat Bot $27.59-78$

Fujita RM (1985) The role of nitrogen status in regulating transient ammonum uptake and nitrogen storage by macroalgae. J Exp Mar Biol Ecol 92:283-301

Gibbs RE (1902) Phyllospadix as a beach-builder. Am Nat 36: $101-109$

Grasshoff K. Ehrhardt M, Kremling K (1983) Methods of seawater analysis. Verlag Chemle, Weinheim

Guerrero MG, Vega JM, Losada M (1981) The assimilatory nitrate-reducing system and its regulation. Ann Rev Plant Physiol 32:169-204

Haines KC, Wheeler PA (1978) Ammonium and nitrate uptake by the marine macrophytes Hypnea musciformis (Rhodophyta) and Macrocystis pyrifera (Phaeophyta). J Phycol 14:319-324

Harrison PJ. Druehl LD (1982) Nutrent uptake and growth in the Laminariales and other Macrophytes: a consideration of methods. In: Srivastava LM (ed) Synthetic and degradative processes in marine macrophytes. $W$ de Gruyter \& Co, New York, p 99-120

Hartnett DC, Bazzaz FA (1983) Physiological integration among intraclonal ramets in Solidago canadensis. Ecology $64: 779-788$

Hemminga MA, Harrison PG, van Lent F (1991) The balance of nutrient losses and gains in seagrass meadows. Mar Ecol Prog Ser 71:85-96

Hemminga MA, Koutstaal BP, van Soelen J, Merks AGA 
(1994) The nitrogen supply to intertidal eelgrass (Zostera marina). Mar Biol 118:223-227

Hillman K, Walker DI, Larkum AWD, McComb AJ (1989) Productivity and nutrient limitation. In: Larkum AWD, McComb AJ, Shepherd SA (eds) Biology of seagrasses. Elsevier, Amsterdam, p 635-685

Hwang SP, Williams SL, Brinkhuis BH (1987) Changes in dissolved nitrogen pools as related to nitrate uptake and assimilation in Gracilaria tikvahiae McLachlan (Rhodophyta). Bot Mar 30:11-19

Iizumi H. Hattori A (1982) Growth and organic production of eelgrass (Zostera marina L.) in temperate waters of the Pacific coast of Japan. III. The kinetıcs of nitrogen uptake. Aquat Bot 12:245-256

Jackson GA (1977) Nutrients and production of giant kelp, Macrocystis pyrifera, off southern California. Limnol Oceanogr 22:979-995

Lapointe BE, Ryther JH (1.979) The effects of nitrogen and seawater flow rate on the growth and biochemical composition of Gracilaria folifera var angustissima in mass outdoor cultures. Bot Mar 22:529-537

McGlathery KJ, Pedersen MF, Borum J (1996) Changes in intracellular nitrogen pools and feedback controls on nitrogen uptake in Chaetomorpha Iinum (Chlorophyta). J Phycol 32:393-401

McRoy CP, Barsdate RJ (1970) Phosphate absorption in eelgrass. Limnol Oceanogr 15:6-13

McRoy CP, Goering JJ (1974) Nutrient transfer between the seagrass Zostera marina and its epiphytes. Nature 248 173-174

McRoy CP, Lloyd DB (1981) Comparative function and stability of macrophyte-based ecosystems. In: Longhurst AR (ed) Analysis of marine ecosystems. Academic Press, London, $p$ 473-489

McRoy CP, McMillan C (1977) Production ecology and physjology of seagrasses. In: McRoy CP, Helfferıch C (eds) Seagrass ecosystems: a scientific perspective. Marcel Dekker, Inc, New York, p 53-87

Moriarty DJW, Boon PI (1989) Interactions of seagrasses with sediment and water In: Larkum AWD, McComb AJ, Shepherd SA (eds) Biology of seagrasses. Elsevier, Amsterdam, p 500-535

O'Brien MC, Wheeler PA (1987) Short term uptake of nutrients by Enteromorpha prolifera (Chlorophyceae). J Phycol 23:547-556

Paling EI, McComb A.J (1994) Nitrogen and phosphorus uptake in seedlings of the seagrass Amphibolis antarctica in Western Australia. Hydrobiologia 294:1-4

Parker HS (1981) Influence of relative water motion on the growth, ammonium uptake, and carbon and nutrogen com position of Ulva latuca (Chlorophyta). Mar Biol 63:309-318

Parsons TR, Maita Y, Lalli CM (1984) A manual of chemical and biological methods for seawater analysis. Pergamon Press, Oxford

Patriquin DG (1972) The origin of nitrogen and phosphorus for growth of the marine angiosperm Thalassia testudinum. Mar Biol 15:35-46

Pedersen MF (1994) Transient ammonium uptake in the macroalga Ulva lactuca (Chlorophyta): nature, regulation and the consequences for choice of measuring technique J Phycol 30:980-986

Pedersen MF, Borum J (1992) Nitrogen dynamics of eelgrass Zostera marina during a late summer period of high growth and low nutrient availability. Mar Ecol Prog Ser 80: $65-73$

Pedersen MF, Borum J (1993) An annual nitrogen budget for a seagrass Zostera marina population. Mar Ecol Prog Ser
101:169-177

Pedersen MF, Paling EI, Walker D I (1997) Nitrogen uptake and allocation in the seagrass Amphibolis antarctica. Aquat Bot (in press)

Penhale PA, Thayer GW (1980) Uptake and transfer of carbon and phosphorus by eelgrass (Zostera marina L.) and its epiphytes. J Exp Mar Biol Ecol 42:113-123

Pérez M, Duarte CM, Romero J, Sand-Jensen K, Alcoverro T (1994) Growth plasticity in Cymodocea nodosa stands: the importance of nutrient supply. Aquat Bot 47:249-264

Pitelka LF, Ashmun JW (1985) Physiology and integration of ramets in clonal plants. In: Jackson JBC. Buss LW, Cook RE (eds) Population biology and evolution of clonal organisms. Yale University Press, New Haven, p 399-435

Ricketts EG, Calvin J, Hedgpeth J, Phillips DW (1985) Between Pacific tides. Stanford University Press, Palo Alto

Roth NC. Pregnall AM (1988) Nitrate reductase activity in Zostera marina. Mar Biol 99:457-463

Segel IH (1968) Biochemical calculations. John Wiley \& Sons, Inc, New York

Short FT (1983) The seagrass Zostera marina L.: plant morphology and bed structure in relation to sediment ammonium in Izembek Lagoon, Alaska. Aquat Bot 16:149-161

Short FT (1987) Effects of sediment nutrients on seagrasses: literature review and mesocosm experiment. Aquat Bot $27: 41-57$

Short FT, McRoy CP (1984) Nitrogen uptake by leaves and roots of the seagrass Zostera marna L. Bot Mar 27(12): $547-555$

Slade AJ, Hutchings MJ (1987a) The effects of light intensity on foraging in the clonal herb Glechoma hederacea. J Ecol $75: 639-650$

Slade AJ, Hutchings MJ (1987b) Clonal integration and plasticity in foraging behaviour in Glechoma hederacea. J Ecol 75:1023-1036

Slade AJ, Hutchings MJ (1987 c) The effects of nutrient availability on foraging in the clonal herb Glechoma hederacea. J Ecol 75:95-112

Sokal RR, Rohlf FJ (1981) Biometry. The principles and practice of statistics in biological research. WH Freeman and Co, New York

Stapel J, Aarts TL, van Duynhoven BHM, de Groot JD, van den Hoogen PHW, Hemminga MA (1996) Nutrient uptake by leaves and roots of the seagrass Thalassia hemprichit (Ehrenb.) Aschers. in the Spermonde Archipielago, Indonesia. Mar Ecol Prog Ser 134:195-206

Stevenson JC (1988) Comparative ecology of submersed grass beds in freshwater, estuarine and marine environments. Limnol Oceanogr 33:867-893

Stewart JG (1989) Maintenance of a balanced, shifting boundary between the seagrass Phyllospadix and algal turf. Aquat Bot 33:223-241

Stewart JG, Myers B (1980) Assemblages of algae and invertebrates in Southern California Phyllospadix-dominated intertidal habitats. Aquat Bot 9:73-94

Thomas TE, Harrison PJ (1985) Effect of nitrogen supply on nitrogen uptake, accumulation and assimilation in Porphyra perforata (Rhodophyta). Mar Bıl 85:269-278

Thursby GB, Harlin MM (1982) Leaf-root interaction in the uptake of ammonia by Zostera marina. Mar Biol 72:109-112

Thursby GB, Harlin MM (1984) Interaction of leaves and roots of Ruppia maritima in the uptake of phosphate, ammonia and nitrate. Már Biol 83:61-67

Tomasko DA, Dawes CJ (1989) Evidence for physılogical integration between shaded and unshaded short shoots of Thalassia testudinum. Mar Ecol Prog Ser 54:299-305

Tomasko DA, Dawes CJ, Hall MO (1991) Effects of the num- 
ber of short shoots and presence of the rhizome apical meristem on the survival and growth of transplanted seagrass Thalassia testudinum. Contrib Mar Sci 32:41-48

Turner T (1983a) Complexity of early and middle successional stages in a rocky intertidal surfgrass community. Oecologia $60: 56-65$

Turner $\mathrm{T}$ (1983b) Facilitation as a successional mechanism in a rocky intertidal community. Am Nat 121:729-738

Turner I (1985) Stability of rocky intertidal surfgrass beds: Persistence, preemption and recovery. Ecology 66:83-92

Turner T, Lucas J (1985) Differences and similarities in the community roles of three rocky intertidal surfgrasses. J Exp Mar Biol Ecol 89:175-189

Whitfield M (1969) Eh as an operational parameter in estuarine studies. Limnol Oceanogr 14:547-558

This article was submitted to the editor
Whitfield M (1974) Thermodynamic limitations on the use of the platinum electrode in Eh measurements. Limnol Oceanogr 19:857-865

Williams SL (1995) Surfgrass (Phyllospadix torreyi) reproduction: reproductive phenology, resource allocation and male rarity. Ecology 76:1953-1970

Williams SL, Herbert SK (1989) Transient photosynthetic responses of nitrogen-deprived Petalonia fascia and Laminaria saccharina (Phaeophyta) to ammonium resupply. J Phycol 25:515-522

Zimmerman RC, Kremer JN (1984) Episodic nutrient supply to a kelp forest ecosystem in Southern California. J Mar Res 42:591-604

ZoBell CE (1946) Studies on redox potential of marine sedxments. Bull Am Assoc Petrol Geol 30:477-513

Manuscript first received: November 7, 1996

Revised version accepted: February 14, 1997 